\title{
RANCANG BANGUN ALAT MONITORING PERKEMBANGAN PASIEN PASCA STROKE BERBASIS IoT (INTERNET of THINGS)
}

\author{
Selviana $^{1)}$, Mery Subito ${ }^{2)}$, Rizana Fauzi ${ }^{3)}$, Alamsyah ${ }^{4)}$ \\ ${ }^{1)}$ Program Studi S1 TeknikElektro, Fakultas Teknik, UniversitasTadulako \\ ${ }^{2,3,4)}$ Dosen Jurusan Teknik Elektro Universitas Tadulako \\ ${ }^{2)}$ email : merysubito62@gmail.com
}

\begin{abstract}
The design of this IoT (Internet of Things)based post-stroke patient monitoring tool was built to monitor patient progress remotely. Flex sensor hardware was used to retrieve data from every movement of the patient's finger muscle strength, then processed by the NodeMCU ESP32 after that the data will be sent to the web server via the IoT platform using a local wireless network. The results of research on the development of post-stroke patients can be displayed to a web server in the form of a table plot of data values for the index finger, middle finger, and ring finger. The post-stroke patient monitoring system can be accessed on $\mathrm{PC}$ and Android devices. The results of the sample test from the device obtained the highest value of 3.26 MMT and the lowest value of 0.2 MMT so that the patient's finger muscle strength was declared unstable and frequent changes in muscle strength.
\end{abstract}

Keywords: monitoring system, Flex sensor, ESP32 NodeMCU, PC.

\section{Pendahuluan}

Stroke merupakan penyakit yang menyebabkan gangguan pada sistem saraf motorik. Hal tersebut akibat dari terganggunya distribusi darah yang menuju ke otak. Setiap tahunnya hampir 15 juta orang didunia mengalami stroke. Di Indonesia sendiri jumlah penderita stroke mencapai 500.000 orang dan diprediksi akan terus mengalami peningkatan setiap tahunnya. Berdasarkan data dari Yayasan Stroke Indonesia pada tahun 2009 jumlah penderita stroke di Indonesia menempati peringkat pertama di Indonesia. Stroke di Indonesia kebanyakan menyerang $35,8 \%$ pasien usia lanjut dan $12,9 \%$ meninggal dunia.[1].
Stroke termasuk dalam penyakit serebrovaskuler (pembuluh darah otak) yang ditandai dengan matinya jaringan otak (infarkserebral) yang terjadi akibat berkurangnya aliran darah dan oksigen kebagian otak. World health organization (WHO) mendefinisikan stroke sebagai gejala gejala deficit dari fungsi susunan saraf yang diakibatkan oleh adanya penyakit pada pembuluh darah dalam otak, bukan karena alasan yang lain. [2]

Salah satu cara yang dapat digunakan untuk mengembalikan fungsi anggota tubuh yang mengalami kelumpuhan adalah dengan melakukan terapi motorik. Namun banyak pasien pasca stroke memilih untuk tidak melakukan terapi. Alasannya antara lain, fasilitas untuk melakukan terapi hanya terdapat pada rumah sakit tertentu saja. Sehingga menyulitkan pasien dengan mobilisasi rendah. Selain itu metode terapi yang monoton cenderung membuat pasien bosan dan menurunkan motivasi berlatih. [3]

Sistem monitoring perkembangan pasien pasca stroke pada manusia berbasis IoT (Internet of Things) merupakan rancangan perangkat keras yang diusulkan peneliti untuk dapat membantu dan memudahkan tenaga medis dalam menangani pasien. Alat ini menggunakan sensor flex dilengkapi dengan NodeMCU ESP32 serta platform IoT web server berfungsi sebagai media pembacaan dan penerima data sensor yang digunakan untuk mempermudah suatu proses monitoring perkembangan kondisi pasien.

Alat yang di kembangkan dalam penelitian ini mampu memonitoring perkembangan pasien stroke tanpa 
menggunakan kabel (wireless). sehingga tenaga medis dengan mudah memonitoring perkembangan pasien stroke. Perancangan alat ini menggunakan NodeMCU ESP32 sebagai pengendali dalam sistem pengontrolan perangkat keras maupun ke platform IoT web server, platform web server yang diusulkan akan terintegrasi personal komputer (PC). Keterlambatan pengiriman data sensor ke platform IoT disebabkan kondisi kecepatan internet yang kurang baik atau tidak setabil.

\subsection{Penyebab Stroke}

Menurut dr. Abdul Ghofir, S.p.s, munculnya serangan stroke dipicu oleh besarnya factor risiko penyakit pendukung lainnya seperti penyakit jantung, saraf, diabetes melitus, darah tinggi, dyslipidemia, obesitas dan usia yang sudah relative tua, yang mana menyebabkan fungus motoric, sensorik, saraf kranialis, dan fungsi kognitif lainnya menjadi lemah. Selain itu, gaya hidup yang kurang sehat juga menjadi factor yang mempercepat datangnya serangan penyakit stroke, seperti kebiasaan merokok, konsumsi alcohol, komsumsi makanan berkolesterol tinggi, dan lain - lain. Angka kejadian penyakit stroke lebih banyak dialami oleh wanita daripada laki - laki dikarenakan perbedaan profil faktor resiko vascular dan substipe dari stroke. Hal itu disebabkan karena wanita memiliki kecacatan stroke yang lebih berat dibandingkan dengan laki - laki. Berikut adalah beberapa terjadinya serangan stroke: 1). Hipertensi, 2). Diabetes Melitius, 3). Merokok, 4). Kurang Olahraga, 5). Obesitas Kegemukan. [2]

\subsection{Kekuatan Otot}

Pengukuran kekuatan otot dilakukan dengan cara menggunakan Manual Muscle Testing (MMT) adalah suatu usaha umtuk menentukan atau mengetahui kemampuan seseorang dalam mengkontraksikan otot secara voluntary, MMT standar sebagai ukuran kekuatan tidak akan sesuai atau cocok untuk seseorang yang tidak dapat mengkontraksikan ototnya secara aktif dan disadari. Adapun kriteria dalam menilai kekuatan otot. Dapat dilihat pada tabel 1 berikut.[4]
Tabel 1 Kriteria Penilaian Otot dengan MMT [4]

\begin{tabular}{|l|l|}
\hline Nilai & \multicolumn{1}{|c|}{ Keterangan } \\
\hline 5 (Normal) & $\begin{array}{l}\text { mampu bergerak normal full } \\
\text { room dengan LGS }\end{array}$ \\
\hline 4 (Good) & $\begin{array}{l}\text { mampu begerak penuh } \\
\text { melawan tahanan minimal } \\
\text { dan melawan tahanan } \\
\text { moderat }\end{array}$ \\
\hline 3 (Fair) & $\begin{array}{l}\text { mampu bergerak dengan } \\
\text { gaya gravitasi tanpa } \\
\text { melawan tahanan }\end{array}$ \\
\hline 2 (Poor) & $\begin{array}{l}\text { adanya kontraksi dengan } \\
\text { gerakan }\end{array}$ \\
\hline 1 (Trace) & adanya kontraksi otot \\
\hline 0 (Zero) & tidak ada kontraksi \\
\hline
\end{tabular}

\subsection{ESP32 NodeMCU}

NodeMCU merupakan sebuah mikrokontrol yang memiliki fungsi yang lebih lengkap dibandingkan dengan mikrokontrol NodeMCU lain seperti Arduino maupun NodeMCU ESP8266. ini memiliki lebih banyak pin input dan output yang dapat digunakan dan mempermudah untuk membuat sebuah sistem yang menggunakan banyak pin. Selain itu juga dilengkapi dengan wi-fi yang memiliki kecepatan lebih dan sebuah Bluetooth low energy dua mode.[5]

Dalam pembuatan modul tugas akhir ini jenis ESP yang digunakan adalah modul ESP32. Modul ESP32 ini memiliki GPIO yang lebih banyak dan memori yang lebih besar dari tipe-tipe dibawahnya, berikut ini merupakan konfigurasi pin outnya dapat dilihat pada gambar 1. [5] 
dikeluarkan dari suatu flex sensor. Sensor flex dapat diaplikasikan pada beberapa perangkat, biasanya digunakan untuk kendali robot,

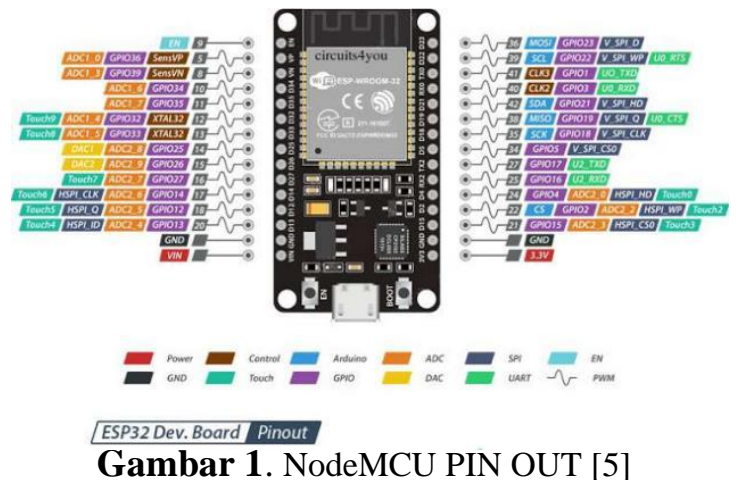

\subsection{IoT ( Internet of Things)}

IoT adalah sebuah konsep dimana objek tertentu memiliki kemampuan untuk mentransfer data melalui jaringan wifi, jadi proses ini tidak memerlukan interaksi dari manusia ke manusia atau manusia ke komputer. Semua sudah dijalankan secara otomatis dengan program. Internet of Things biasa disebut dengan IoT, dan teknologi ini sudah berkembang pesat mulai dari teknologi nirkabel, micro-electromechanical systems (MEMS) dan internet. Menurut metode identifikasi RFID (Radio Frequency Identification), istilah IoT tergolong dalam metode komunikasi, meskipun IoT juga dapat mencakup teknologi sensor lainnya, teknologi nirkabel atau kode QR (Quick Response). IoT sebenarnya adalah konsep yang cukup sederhana, yang artinya menghubungkan semua objek fisik di kehidupan sehari-hari ke Internet. Istilah "Internet of Things" terdiri atas dua bagian utama yaitu Internet yang mengatur konektivitas dan Things yang berarti objek atau perangkat. Enam prinsip dasar yang menopang IoT.[6]

\subsection{Sensor Flex}

Sensor flex adalah sensor yang berfungsi untuk mendeteksi suatu kelengkungan atau tekukan jari-jari tangan. Prinsip kerjanya sama dengan potensiometer. Untuk menggunakan sensor flex, kita membutuhkan bantuan ESP32 yang digunakan sebagai mikrokontroler untuk membaca data ADC berupa tegangan yang sebagai pembaca isarat tangan digital, serta sebagai pembaca gerakan jari-jari tangan. Dapat dilihat pada gambar 2. [6]

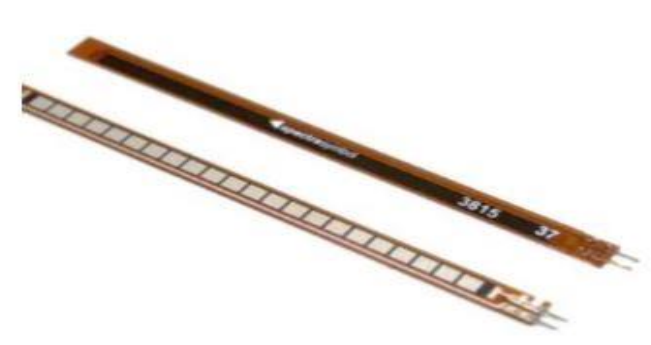

Gambar 2. Bentuk Fisik Sensor Flex [6]

Adapun prinsip kerja dari sensor flex dapat dilihat seperti yang dijelaskan pada gambar 3 .

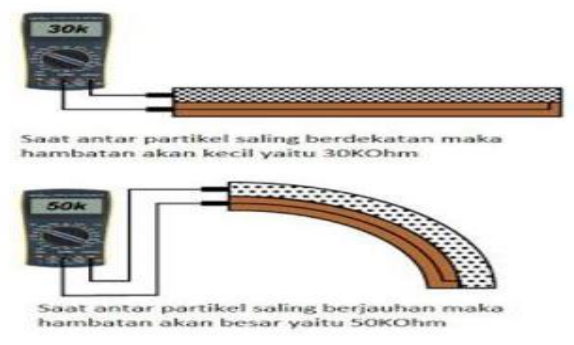

Gambar 3. Prinsip Kerja Sensor Flex [6]

Prinsip kerja dasar dari sensor flex adalah ketika sensor flex tidak ditekuk (dalam kondisi lurus) maka partikel didalam sensor saling berdekatan, sehingga nilai hambatan akan menjadi kecil yaitu berkisar $30 \mathrm{KOhm}$. Sedangkan ketika sensor ditekuk maka partikel di dalam sensor akan saling berjauhan sehingga mengakibatkan membesarnya nilai hambatan, yaitu $50 \mathrm{KOhm}$.

\subsection{Rangkaian Sensor Flex}

Sensor flex atau disebut juga sensor kelenturan berfungsi untuk membaca fleksibilitas dan lekukan dari sensor tersebut. Output dari sensor tersebut berupa tegangan analog yang dapat lansung dihubungkan dan dibaca oleh mikrokontroler melalui fasilitas ADC. Rangkaian dasar sensor flex dapat dilihat pada gambar 4. [6] 


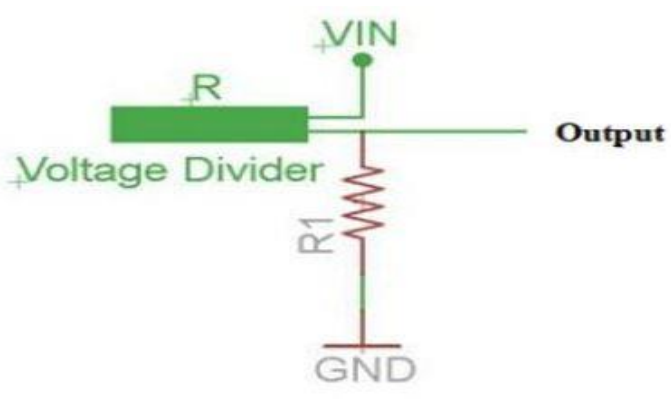

Gambar 4. Rangkaian Sensor Flex [6]

\subsection{Arduino IDE}

Sebuah perangkat lunak yang memudahkan kita mengembangkan aplikasi mikrokontroler mulai dari menuliskan source program, kompilasi, upload hasil kompilasi, dan uji coba secara terminal serial.

Arduino IDE ini bisa dijalankan di komputer dengan berbagai macam platform karena didukung atau berbasis Java. Source program yang kita buat untuk aplikasi mikrokontroler adalah bahasa $\mathrm{C} / \mathrm{C}++$ dan dapat digabungkan dengan assembly. Penulis menggunakan arduino berbasis mikrokontroler AVR dilingkungan jenis ATMEGA yaitu ATMEGA 8, 168, 328 dan 2650. [7]

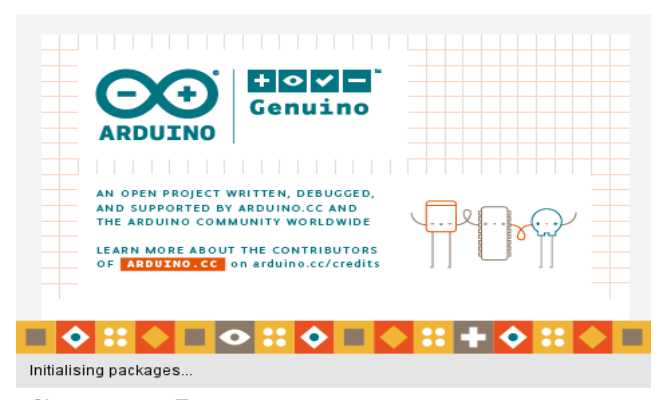

Gambar 5. Tampilan awal arduino IDE [7]

\subsection{Web Server}

Server web atau yang dalam bahasa inggris disebut web server adalah perangkat lunak (software) dalam server yang berfungsi untuk menerima permintaan (request) berupa halaman web melalui protokol HTTP dan atau HTTPS dari klien yang lebih dikenal dengan nama browser, kemudian mengirimkan kembali (respon) hasil permintaan tersebut ke dalam bentuk halaman-halaman web yang pada umumnya berbentuk dokumen HTML.[8]

\subsection{Personal Computer (PC)}

Personal computer adalah seperangkat komputer yang digunakan oleh satu orang pribadi saja. Fungsi utama dari PC adalah untuk mengolah data input dan menghasilkan output berupa data atau informasi sesuai dengan keinginan pengguna. Dalam pengelolaan data dari mulai memasukkan (input) data sampai akhirnya dapat menghasilkan (output) informasi. [8]

\section{Metode Penelitian}

\subsection{Alat dan Bahan Penelitan}

Dalam penyusunan dan pembuatan skrispsi yang berjudul Rancang Bangun Alat Monitoring Perkembangan Pasien Pasca Stroke berbasis IoT (Internet of Things), akan digunakan beberapa macam alat dan bahan sebagai berikut :

\subsubsection{Bahan Penelitian}

Bahan Penelitian terdiri dari tiga jenis, yaitu sensor Flex, manusia dan program. Sensor Flex digunakan sebagai bahan untuk dapat mendeteksi pergerakan jari tangan pasien pasca stroke, manusia digunakan sebagai bahan pengambilan data pergerakan setiap tekukan jari - jari tangan pasien pasca stroke. program digunakan sebagai bahan dalam mendukung software maupun hardware agar dapat menghasilkan tampilan output yang diinginkan.

\subsubsection{Alat Penelitian}

Adapun alat-alat yang digunakan pada penelitian ini antara lain ESP832 nodeMCU sebagai pengontrollan dan pengiriman data, perangkat lunak (software) Arduino IDE sebagai media penginputan data, platform IoT sebagai media tampilan hasil data, serta PC sebagai penerima dan server pendukung tampilan data

\subsection{Teknik Penelitian}

Teknik penelitian yang dilakukan pada penelitian ini yaitu merancang alat untuk 
memonitoring pergerakan jari - jari tangan pasien berupa sarung tangan dimana terdapat 3 sensor flex yang diletakkan pada jari telunjuk, jari tengah, jari manis untuk mengetahui kekuatan otot. Kemudian data pasien akan dideteksi oleh sensor flex, lalu diteruskan melalui serial komunikasi ke mikrokontroler yang ada pada NodeMCU. Sehingga data tersebut akan dikelola NodeMCU dan dikirim melalui modul ESP32 agar dapat ditampilkan pada web server dan di akses pada PC.

\section{Hasil dan Pembahasan}

\subsection{Data Hasil Penelitian}

Data hasil penelitian diperoleh dalam bentuk alat, software, data, maupun analisis data. Hasil perancangan dan penelitian yang telah dilakukan dapat dilihat pada gambar 6 berikut.

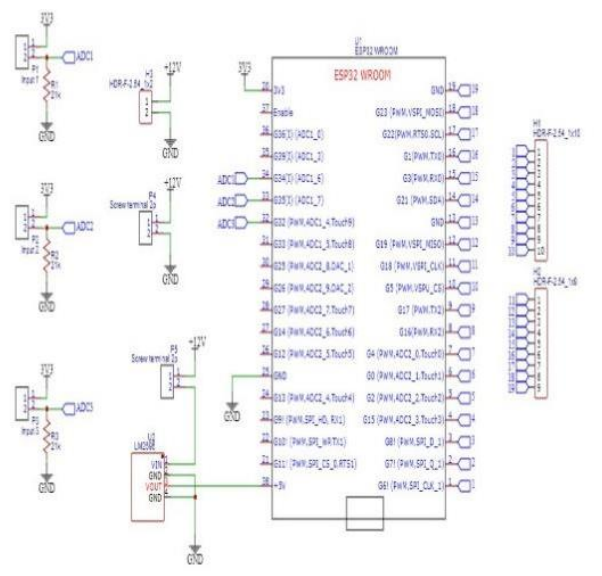

Gambar 6. Skematik rangkaian Perangkat Keras

Tabel 2. Hasil Monitoring Perkembangan Pasien pertama ibu Fitriani yang berumur 45 tahun.

\begin{tabular}{|l|l|l|l|l|l|l|l|l|l|l|}
\hline \multirow{2}{*}{ No } & \multirow{3}{*}{ Waktu } & \multicolumn{3}{|c|}{ Kontraksi } & \multicolumn{2}{|c|}{ Kontraksi \& Gerakan } & \multicolumn{3}{|c|}{ Gravitasi } \\
\cline { 3 - 10 } & $\begin{array}{l}\text { Jari } \\
\text { telunjuk }\end{array}$ & $\begin{array}{l}\text { Jari } \\
\text { tengah }\end{array}$ & $\begin{array}{l}\text { Jari } \\
\text { manis }\end{array}$ & $\begin{array}{l}\text { Jari } \\
\text { telunjuk }\end{array}$ & $\begin{array}{l}\text { Jari } \\
\text { tengah }\end{array}$ & $\begin{array}{l}\text { Jari } \\
\text { manis }\end{array}$ & Jari & Jari & Jari \\
telunuk & tengah & manis \\
\hline 1. & $\begin{array}{l}\text { Minggu } \\
\text { Pertama }\end{array}$ & 0,29 & 0,11 & 0,17 & 1,9 & 1,3 & 1,22 & 2,1 & 1,08 & 1,86 \\
\hline 2. & $\begin{array}{l}\text { Minggu } \\
\text { Kedua }\end{array}$ & 0,45 & 0,21 & 0,28 & 1,86 & 1,31 & 1,45 & 2,87 & 1,52 & 1,97 \\
\hline 3. & $\begin{array}{l}\text { Minggu } \\
\text { Ketiga }\end{array}$ & 0,56 & 0,34 & 0,4 & 2,25 & 1,22 & 1,65 & 2,8 & 1,58 & 2,1 \\
\hline 4. & $\begin{array}{l}\text { Minggu } \\
\text { Keempat }\end{array}$ & 0,59 & 0,29 & 0,68 & 2,29 & 1,61 & 1,94 & 3,26 & 1,52 & 2,15 \\
\hline
\end{tabular}

Tabel 3. Hasil Monitoring Perkembangan Pasien kedua bapak Usman yang berumur 52 tahun.

\begin{tabular}{|c|c|c|c|c|c|c|c|c|c|c|}
\hline \multirow[b]{2}{*}{ No } & \multirow[b]{2}{*}{ Waktu } & \multicolumn{3}{|c|}{ Kontraksi } & \multicolumn{3}{|c|}{ Kontraksi \& Gerakan } & \multicolumn{3}{|c|}{ Gravitasi } \\
\hline & & $\begin{array}{l}\text { Jari } \\
\text { telunjuk }\end{array}$ & $\begin{array}{l}\text { Jari } \\
\text { tengah }\end{array}$ & $\begin{array}{l}\text { Jari } \\
\text { manis }\end{array}$ & $\begin{array}{l}\text { Jari } \\
\text { telunjuk }\end{array}$ & $\begin{array}{l}\text { Jari } \\
\text { tengah }\end{array}$ & $\begin{array}{l}\text { Jari } \\
\text { manis }\end{array}$ & $\begin{array}{l}\text { Jari } \\
\text { telunjuk }\end{array}$ & $\begin{array}{l}\text { Jari } \\
\text { tengah }\end{array}$ & $\begin{array}{l}\text { Jari } \\
\text { manis }\end{array}$ \\
\hline 1. & $\begin{array}{l}\text { Minggu } \\
\text { Pertama }\end{array}$ & 0,18 & 0,28 & 0,14 & 1,95 & 1,02 & 1,44 & 1,93 & 1,02 & 1,59 \\
\hline 2. & $\begin{array}{l}\text { Minggu } \\
\text { Kedua }\end{array}$ & 0,3 & 0,58 & 0,6 & 1,32 & 1,1 & 1,28 & 2,07 & 1,05 & 1,64 \\
\hline 3. & $\begin{array}{l}\text { Minggu } \\
\text { Ketiga }\end{array}$ & 0,8 & 0,62 & 0,93 & 2,14 & 1,31 & 1,86 & 3,21 & 1,39 & 2,02 \\
\hline 4. & $\begin{array}{l}\text { Minggu } \\
\text { Keempat }\end{array}$ & 0,31 & 0,98 & 0,88 & 2,93 & 1,7 & 1,75 & 2,99 & 2,15 & 2,25 \\
\hline
\end{tabular}

Tabel 4. Hasil Monitoring Perkembangan Pasien ketiga bapak Sartono yang berumur 55 tahun

\begin{tabular}{|l|l|l|l|l|l|l|l|l|l|l|}
\hline \multirow{2}{*}{ No } & \multirow{3}{*}{ Waktu } & \multicolumn{3}{|c|}{ Kontraksi } & \multicolumn{3}{c|}{ Kontraksi \& Gerakan } & \multicolumn{3}{c|}{ Gravitasi } \\
\cline { 3 - 10 } & $\begin{array}{l}\text { Jari } \\
\text { telunjuk }\end{array}$ & $\begin{array}{l}\text { Jari } \\
\text { tengah }\end{array}$ & $\begin{array}{l}\text { Jari } \\
\text { manis }\end{array}$ & $\begin{array}{l}\text { Jari } \\
\text { telunjuk }\end{array}$ & $\begin{array}{l}\text { Jari } \\
\text { tengah }\end{array}$ & $\begin{array}{l}\text { Jari } \\
\text { manis }\end{array}$ & $\begin{array}{l}\text { Jari } \\
\text { telunjuk }\end{array}$ & $\begin{array}{l}\text { Jari } \\
\text { tengah }\end{array}$ & $\begin{array}{l}\text { Jari } \\
\text { manis }\end{array}$ \\
\hline 1. & $\begin{array}{l}\text { Minggu } \\
\text { Pertama }\end{array}$ & 0,2 & 0,17 & 0,25 & 1,88 & 1,1 & 1,65 & 2,12 & 1,04 & 1,23 \\
\hline 2. & $\begin{array}{l}\text { Minggu } \\
\text { Kedua }\end{array}$ & 0,29 & 0,33 & 0,31 & 1,93 & 1,87 & 1,11 & 1,88 & 1,31 & 1,46 \\
\hline 3. & $\begin{array}{l}\text { Minggu } \\
\text { Ketiga }\end{array}$ & 0,19 & 0,27 & 0,41 & 1,9 & 1,29 & 1,48 & 2,68 & 1,41 & 1,86 \\
\hline 4. & $\begin{array}{l}\text { Minggu } \\
\text { Keempat }\end{array}$ & 0,7 & 0,39 & 0,62 & 1,85 & 1,88 & 2,7 & 2,52 & 1,94 & 1,61 \\
\hline
\end{tabular}

Tabel 5. Hasil Monitoring Perkembangan Pasien keempat bapak Mapiasi yang berumur 50 tahun.

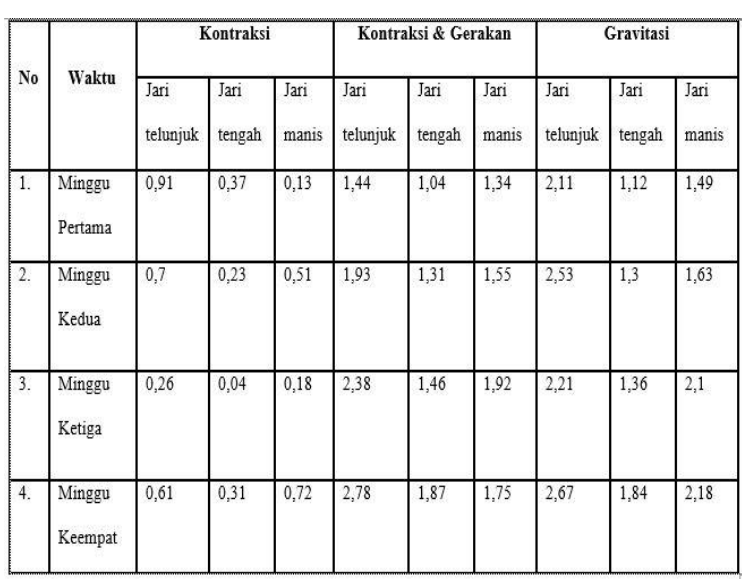




\subsection{Pembahasan}

Berdasarkan Tabel 2, Tabel 3, dan Tabel 4 dan Tabel 5. dilakukan tiga kali percobaan untuk mengukur tingkat keakuratan sensor kemudian dilakukan perhitungan nilai error dan analisa. Dari data tersebut dibuat dalam bentuk grafik perkembangan monitoring pasien pasca stroke serta analisa tingkat keberhasilan setiap sensor bekerja.

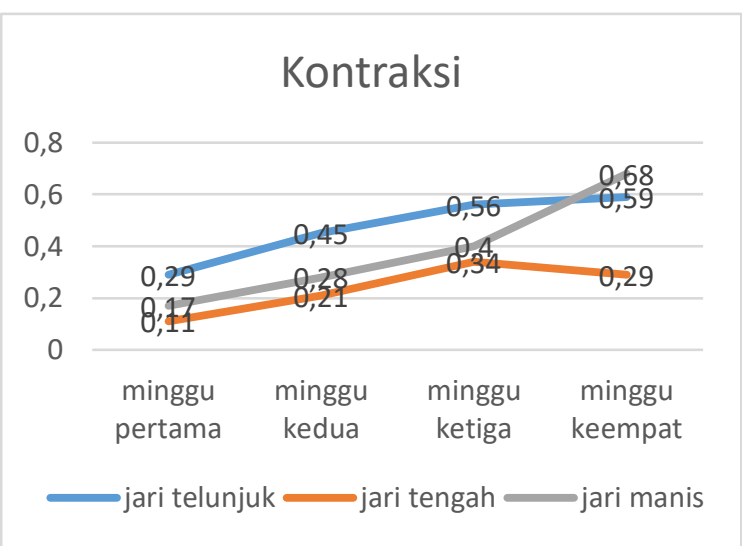

Gambar 7. Grafik Perkembangan Gaya Kontraksi Pasien Pertama berumur 45 tahun.

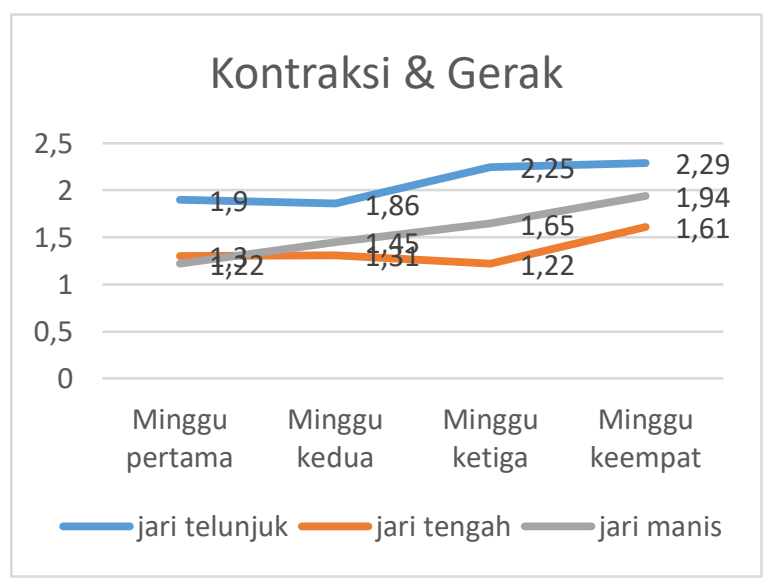

Gambar 8. Grafik Perkembangan Gaya Kontraksi dan Gerakan Pasien Pertama berumur 45 tahun.

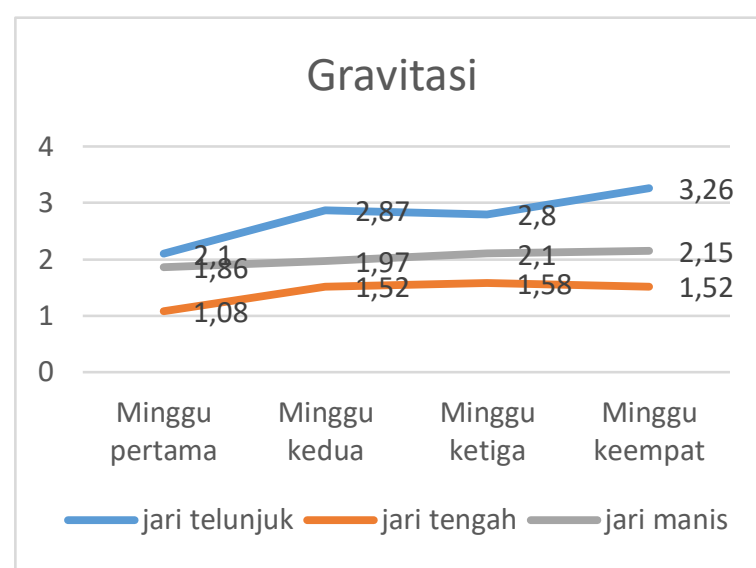

Gambar 9. Grafik Perkembangan Gaya Gravitasi Pasien Pertama

Berdasarkan gambar 7 dan gambar 8 dapat dilihat bahwa perkembangan pergerakan jari tangan pada percobaan kondisi gaya kontraksi serta kontraksi dan gerakan dengan 4 kali percobaan dalam rentang waktu 4 minggu mengalami perkembangan. Namun hal tersebut belum mencapai nilai normal MMT (Manual Muscle Testing) karena disebabkan oleh kekuatan otot pada jari tangan pasien masih lemah sehingga, tidak mencapai nilai maksimal. Berdasarkan gambar 9. dapat dilihat bahwa pergerakan jari tangan pasien pada percobaan kondisi gaya gravitasi dengan 4 kali percobaan dalam rentang waktu selama empat minggu mengalami peningkatan pada jari telunjuk dan jari manis. Sedangkan pada jari tengah mengalami penurunan nilai pada minggu keempat disebabkan karena rentang sensor flex terhadap kaos tangan yang digunakan serta kekuatan otot jari tangan pasien yang tidak bisa diprediksi. 


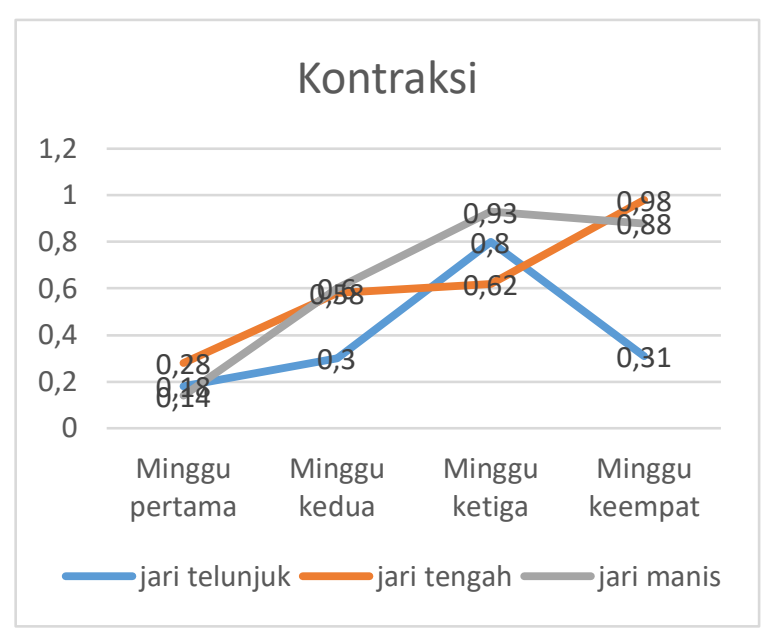

Gambar 10. Grafik Perkembangan Gaya Kontraksi Pasien Kedua

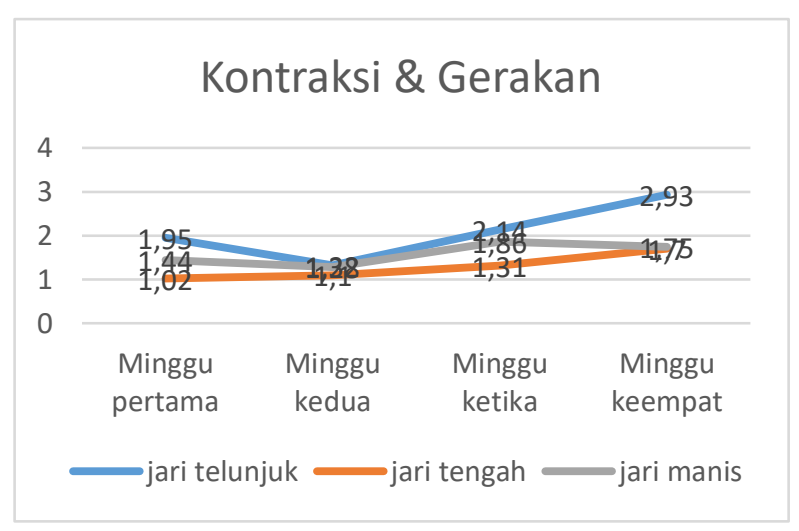

Gambar 11. Grafik Perkembangan Gaya Kontraksi dan Gerakan Pasien Kedua

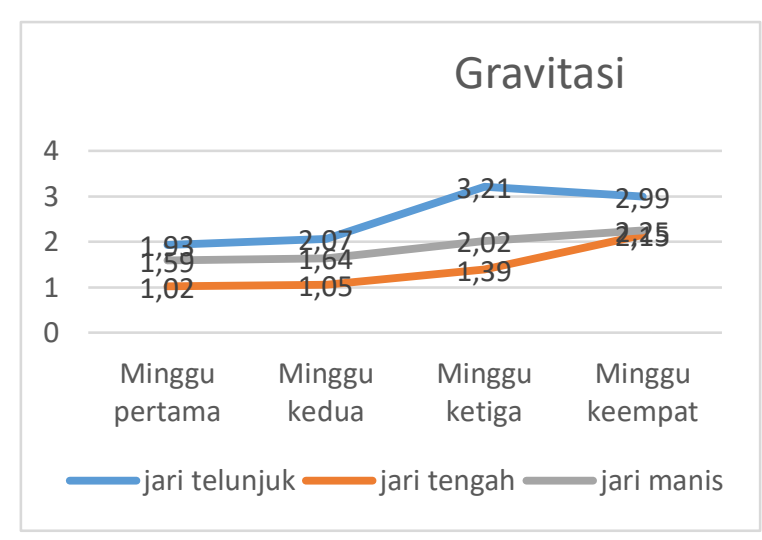

Gambar 12. Grafik Perkembangan Gaya Gravitasi Pasien Kedua
Berdasarkan gambar 10 dapat dilihat bahwa perkembangan pergerakan jari tangan pasien pada percobaan kondisi gaya kontraksi dengan 4 kali percobaan dengan rentang waktu selama 4 minggu. Berdasarkan grafik diatas dapat disimpulkan bahwa untuk jari telunjuk dan jari manis pada minggu keempat mengalami penurunan, hal ini dapat disebabkan karena perubahan pada resistansi sensor pada masing -masing jari tidak sama karena, faktor suhu, kelembapan, dan toleransi nilai resistansi dari sensor flex tersebut. Berdasarkan gambar 11 disimpulkan bahwa pada jari manis diminggu kedua dan keempat mengalami penurunan namun pada minggu ketiga mengalami peningkatan. Hal ini dapat disebabkan oleh menurunnya kekuatan otot jari manis pada pasien. Berdasarkan gambar 12 perkembangan gaya gravitasi jari pasien dapat disimpulkan bahwa pada jari tengah dan jari manis mengalami perkembangan hingga minggu keempat. sedangkan pada jari telunjuk mengalami penurunan yang disebabkan oleh kekuatan otot pasien menurun sehingga tidak mampu menekuk dan melakukan gaya gravitasi dengan tahanan minimal.

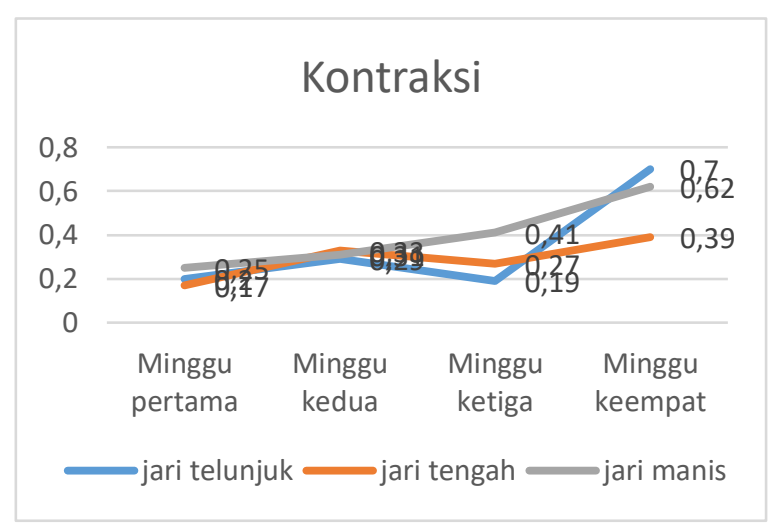

Gambar 13. Grafik Perkembangan Gaya Kontraksi Pasien Ketiga 


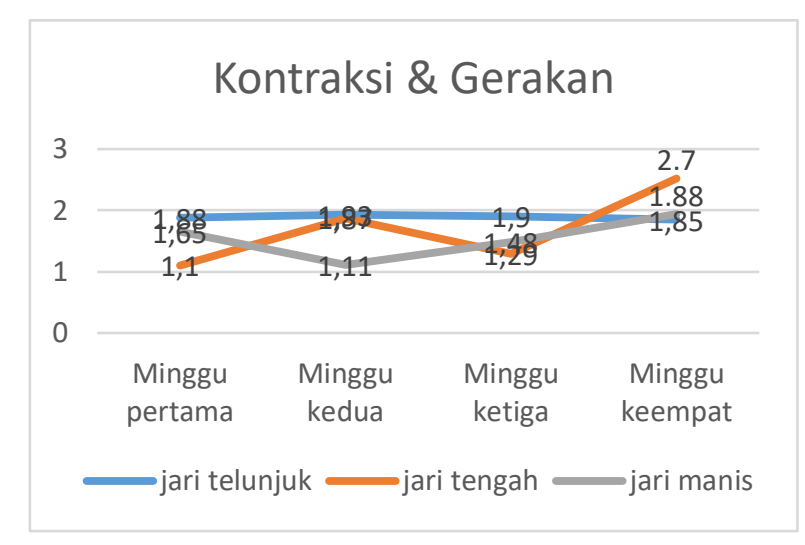

Gambar 14. Grafik Perkembangan Gaya Kontraksi dan Gerakan Pasien Ketiga

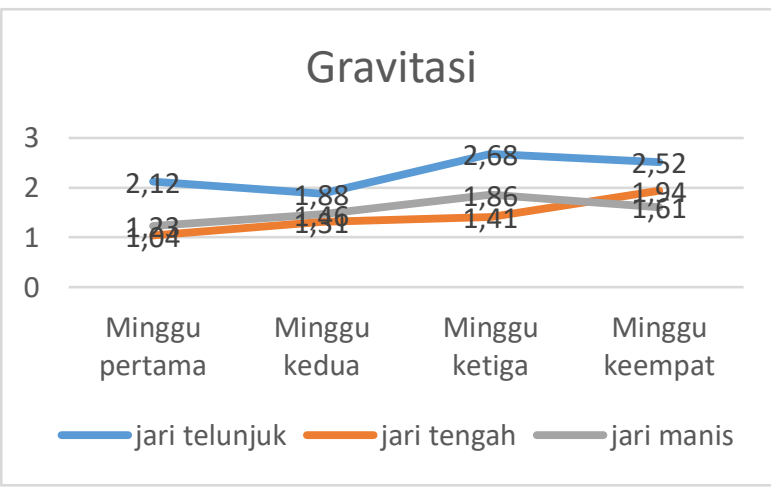

Gambar 15. Grafik Perkembangan Gaya Gravitasi Pasien Ketiga

Berdasarkan gambar 13 perkembangan pergerakan jari tangan pasien pada percobaaan kondisi gaya kontraksi 4 kali percobaan dalam rentang waktu selama 4 minggu dapat disimpulkan bahwa pada jari tengah dan jari telunjuk minggu ketiga mengalami penurunan, sedangkan pada jari manis mengalami peningkatan. Hal ini disebabkan oleh kekuatan otot masing - masing jari pasien tidak sama. Berdasarkan gambar 14 dimana gaya perkembangan gaya kontraksi dan gerak pasien dapat disimpulkan bahwa pada jari tengah pada minggu kedua mengalami peningkatan. Namun, pada minggu ketiga dan keempat menurun. Sedangkan jari manis mengalami penurunan diminggu kedua dan ketiga serta jari tengah pada minggu ketiga menurun. Hal ini disebabkan kekuatan otot pasien berubah - ubah sehingga kemampuan pasien mengerakkan jari - jari tangan sangatlah berpengaruh. Pada gambar 15 perkembangan pergerakan gaya gravitasi jari pasien dapat disimpulkan bahwa pada jari telunjuk dan jari manis mengalami penurunan pada minggu keempat. hal ini disebabkan oleh semangat pasien dalam melakukan terapi.

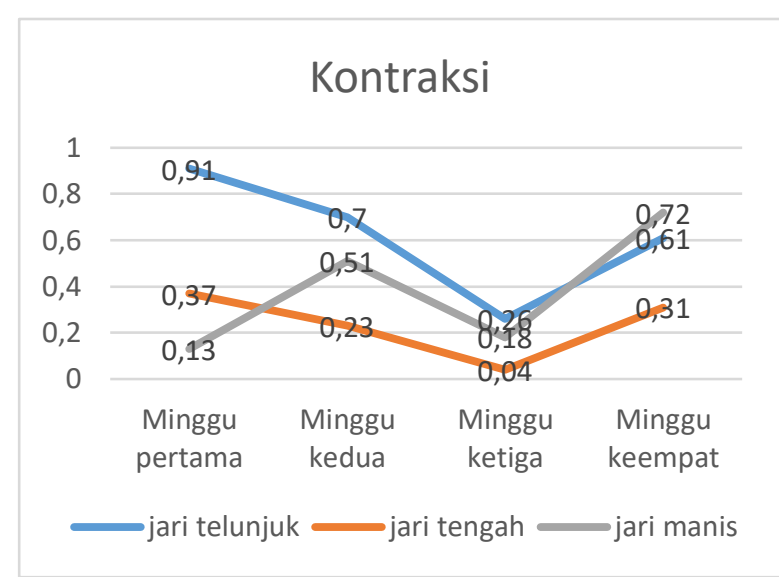

Gambar 16. Grafik Perkembangan Gaya Kontraksi Pasien Keempat

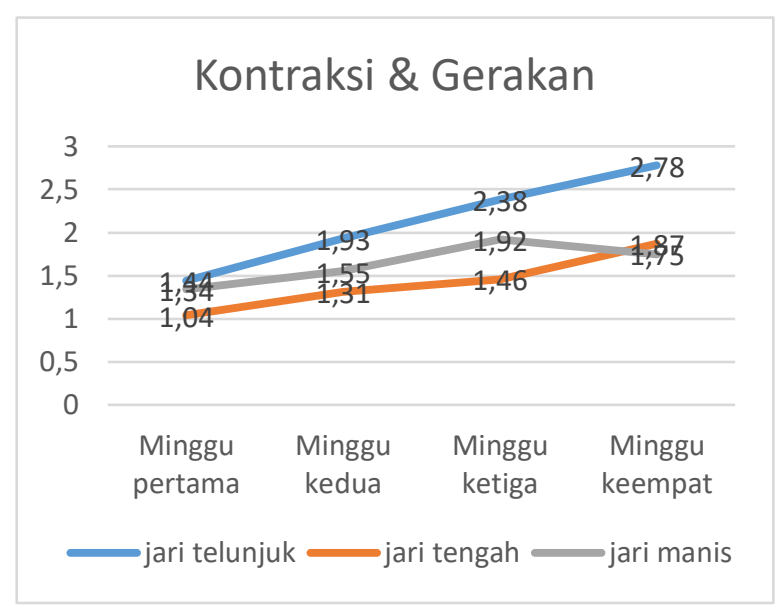

Gambar 17. Grafik Perkembangan Gaya Kontraksi dan Gerakan Pasien Keempat 


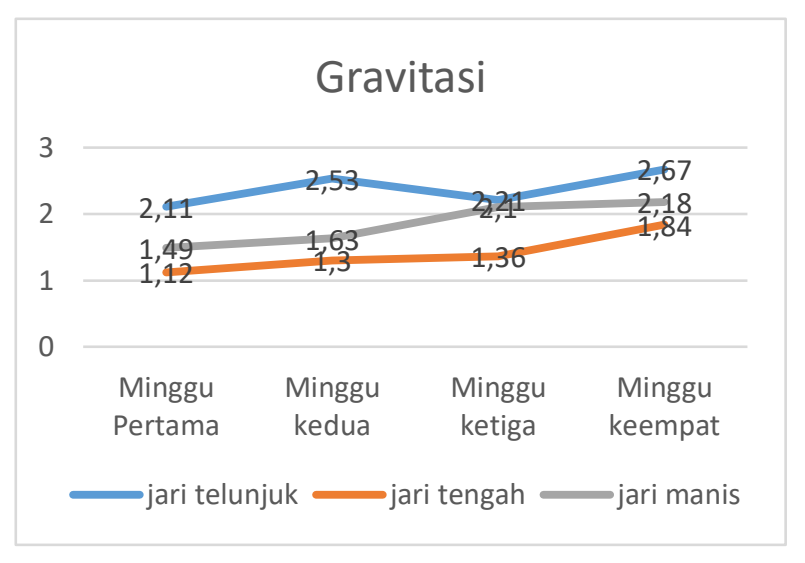

Gambar 18. Grafik Perkembangan Gaya Gravitasi Keempat

Berdasarkan gambar 16 perkembangan pergerakan jari tangan pasaien pada percobaan kondisi gaya kontraksi 4 kali percobaan dalam rentang waktu selama 4 minggu dapat disimpulkan bahwa pada jari telunjuk dan jari tengah penurunan. Berdasarkan gambar 17 percobaan kondisi gaya kontraksi dan gerak dapat disimpulkan bahwa pada jari tengah dan jari telunjuk diperoleh hasil yang baik dari minggu pertama hingga minggu keempat mengalami perkembangan sedangkan jari manis minggu keempat mengalami penurunan. Berdasarkan gambar 18 percobaan kondisi gaya gravitasi dapat disimpulkan bahwa jari telunjuk diminggu ketiga mengalami penurunan. Hal ini disebabkan oleh pengaruh kekuatan otot jari tangan pasien yang belum stabil sehingga sering terjadinya perubahan. Sedangkan pada jari tengah dan manis diperoleh nilai yang tinggi dari minggu sebelumnya. Proses terjadinya penurunan dan peningkatan kondisi kekuatan otot masing masing jari sehingga dapat terjadi hasil yang berbeda.

\section{Kesimpulan}

Dari data hasil perancangan dan penelitian yang telah dilakukan pada tugas akhir yang berjudul Rancang Bangun Alat
Monitoring Pasien Pasca Stroke Berbasis IoT (internet of things) maka $\mathrm{di}$ peroleh kesimpulan sebagai berikut :

1. Sensor Flexsibel sebagai alat yang dapat memonitoring pergerakan jari tangan manusia dengan berbasis IoT. dengan tujuan memudahkan tenaga medis untuk memantau keadaan pasien stroke yang dalam tahap penyembuhan atau masa terapi dengan melihat data yang ditampilkan pada web server.

2. Modul NodeMCU di gunakan sebagai pemproses atau pengelola data, dimana data yang telah didapatkan dari sensor flex akan ditampilkan pada web server dan di akses pada PC atau Android

3. Hasil Pengujian berdasarkan parameter nilai EMT Gaya Kontraksi, Gaya Kontraksi Gerakan, dan Gaya Gravitasi yang digunakan oleh Fisioterapi menunjukkan nilai pergerakan jari tangan masing masing pasien berbeda - beda dan kekuatan otot setiap jari tidak dapat diprediksi sehinga dapat terjadi penurunan dan peningkatan kekuatan otot. Hal ini disebabkan karena setiap pasien belum maksimal dalam mengerakkan jari tangan dan membutuhkan waktu yang cukup lama untuk terus melakukan terapi agar sistem saraf setiap jari terlatih dan terbiasa untuk digerakkan. Hasil pengujian keempat sampel dari perangkat diperoleh nilai tertinggi 3,26 mmt pada sensor jari telunjuk dan nilai terendah $0.2 \mathrm{mmt}$ pada sensor jari telunjuk, hal ini dapat disebabkan oleh pengaruh kekuatan otot jari tangan pasien yang belum stabil sehingga sering terjadinya perubahan.

4. Dengan teknologi IoT (Internet of Things) data hasil keluaran sensor flex dapat dikirim ke web server melalui jaringan local.

5. Pada penelitian ini penulis tidak dapat membandingkan alat yang telah dibuat. dikarenakan untuk mengontrol kekuatan jari tangan pada pasien pasca stroke tidak memiliki alat dan pihak fisioterapi dan rehabilitas hanya menggunakan nilai MMT (Manual Muscle Testing) yang tak terukur sebagai parameter dalam melihat kondisi perkembangan pasien pasca stroke dalam tahap penyembuhan 


\section{DAFTAR PUSTAKA}

[1] Syareza, R, S., Oktiasari, R., Madona, P., Susianti, E., \& Muzti Sahar. 2018. Alat Bantu Terapi Pasca Stroke Untuk Tangan. Riau: Jurnal Politeknik Caltex. 4(5).

[2] Hargiani X. F. 2019. Case Study Aplikasi Neuromuscular Taping Kasus Bells' Palsy Pada Pengalaman Praktek Fisioterapi Di Klinik Kineta Sidoarjo. Stikes Delima Persada Gresik. Jurnal Ilmiah Fisioterapi. 2(1).

[3] Marifah. A. Rancang Bangun Sistem Perekaman Sinyal EMG Untuk Monitoring Perkembangan Pasien Pasca Stroke. Surabaya: Universitas Airlangga.

[4] Kuswardani, Abidin Z, Amanati S. 2019. Pengaruh Terapi Latihan Dan Kinesio Taping Pada Lesi Nerve Peroneus E.C Kusta. Jurnal Fisioterapi dan Rehabilitasi. 3(1)

[5] Setiawan \& Purnamasari 2019. Pengembangan Smart Home Dengan Microcontrollers ESP32 Dan MC-38 Door Magnetic Switch Sensor Berbasis Internet of Things (IoT). Jurnal Elektronika

[6] Yudhana A., 2019. Proyek Instrumentasi Medis Berbasis Internet of Things. Yogyakarta: CV Mine.

[7] Cholis N. 2020. Rancang Bangun Tangan Bionik Untuk Membantu Pasien Pasca Operasi. Palu: Universitas Tadulako

[8] Solihin A. 2019. Sistem Monitoring Realtime Detak Jantung Dan Kadar Oksigen Dalam Darah Pada Manusia Berbasis Iot (Internet Of Things). Palu: Universitas Tadulako. 